\title{
Social Engagement Network and Corporate Social Entrepreneurship in Sido Muncul Company, Indonesia*
}

\author{
Hani SIRINE ${ }^{1}$, Roos Kities ANDADARI ${ }^{2}$, Lieli SUHARTI ${ }^{3}$
}

Received: August 01, 2020 Revised: October 05, 2020 Accepted: October 15, 2020

\begin{abstract}
The purpose of this study was to determine the social engagement network in Sido Muncul's CSR, the partnership program with farmers, and how the implementation of corporate social entrepreneurship in the program is carried out. The research design uses qualitative methods with a grounded theory approach that tests the validity and reliability of the data using triangulation of data sources and methods, namely, data obtained through documentation and the results of surveys and interviews to more than one observation unit. Data was obtained from surveys and interviews with Sido Muncul's Public Relations and CSR Division, as well as partner farmers. The results of this study indicate that the social engagement network in Sido Muncul's partnership program is related to the role of farmer groups, farmer cooperatives, government, NGOs, universities, and private companies as facilitators and control functions, thus creating mutually beneficial relationships with one another. The process of implementing corporate social entrepreneurship in Sido Muncul's CSR for the partnership program with farmers consists of nine stages: problem identification, coordination with related parties, allocation of resources and commitments, collaboration with NGOs, local entrepreneurs and government, social innovation and the creation of new businesses, documentation of activities, reporting, monitoring and evaluation, as well as publications.
\end{abstract}

Keywords: Social Engagement Network, Corporate Social Entrepreneurship, Corporate Social Responsibility

JEL Classification Code: L14, L31, M14

\section{Introduction}

Global social and environmental challenges such as poverty alleviation, climate change, scarcity of resources, and loss of biodiversity prompt discussion of how business

\footnotetext{
*Acknowledgments:

We thank you for the support from Satya Wacana Christian University in terms of scientific development and funding, so that this research can be completed.

${ }^{1}$ First Author and Corresponding Author. Lecturer, Faculty of Economics and Business, Satya Wacana Christian University, Indonesia [Postal Address: Diponegoro Street Number 52-60, Salatiga, Central Java, 50711, Indonesia]

Email: hani.sirine@uksw.edu

'Lecturer, Faculty of Economics and Business, Satya Wacana Christian University, Indonesia. Email: roos.kities@uksw.edu

${ }^{3}$ Lecturer, Faculty of Economics and Business, Satya Wacana Christian University, Indonesia. Email: lieli.suharti@uksw.edu

(c) Copyright: The Author(s)

This is an Open Access article distributed under the terms of the Creative Commons Attribution Non-Commercial License (https://creativecommons.org/licenses/by-nc/4.0/) which permits unrestricted non-commercial use, distribution, and reproduction in any medium, provided the original work is properly cited.
}

can create greater social value (Michelini, 2012). Businesses are not solely seen from their financial performance, but also from corporate social responsibility, which is a means to increase organizational commitment (Nguyen \& Tu, 2020) and a company's strategy to increase its brand equity (Zahari et al., 2020). Machmuddah et al. (2020) add that the implementation of corporate social responsibility is very important to increase company value and the sustainability of the company in the future.

Mushka (2015) suggests that companies involve stakeholders in developing issues and alternative perspectives that are more comprehensive about community expectations of long-term social and environmental impacts, so as to facilitate the decision-making process. Companies can get social and economic benefits by investing in corporate social responsibility to create social entrepreneurship (Agrawal \& Sahasranamam, 2016). In relation to social entrepreneurship and corporate social responsibility, a new concept has emerged, namely, corporate social entrepreneurship, which is considered as corporate entrepreneurship with a mission to solve social problems and create social value (Crisan \& Borza, 2012). 
According to Raimi et al. (2015), corporate social entrepreneurship can be a strong antidote to poverty, insecurity and underdevelopment. Spitzeck et al. (2013) found that corporate social entrepreneurship approaches to differentiate from competitors and create shared value, and use societal sustainability challenges to innovate. Zaefarian et al. (2015) produce a corporate social entrepreneurship model that has an impact on the company, including improving company performance, prevention or exit strategies from organizational crises and achieving organizational commitment. The findings of Nikolov and Westergren's (2017) research are that corporate social entrepreneurship is part of the company's long-term strategy, which is integrated with business processes. The research results of Agrawal and Sahasranamam (2016) state that corporate social entrepreneurship is related to marketing strategies, improving the quality of life of the poor, as well as long-term legitimacy and profitability. The majority of researchers discussed the impact of corporate social entrepreneurship, so this study will examine social engagement networks and the implementation process of corporate social entrepreneurship at Sido Muncul Herbal Medicine and Pharmacy Company.

Sido Muncul is a company established in 1951 and is a modern herbal company that always strives to provide good and healthy products for all its consumers, and thus provide positive value to society. Sido Muncul Herbal Medicine and Pharmacy Company has succeeded in gaining the highest market share and a good reputation as the largest herbal medicine industry in Indonesia. In addition, Sido Muncul has implemented corporate social responsibility related to the concept of corporate social entrepreneurship, where the CSR program becomes a system that is integrated with the company's business processes, resulting in shared value. Large industries cannot run alone, they must cooperate with small- and medium-sized businesses (SMEs), so that Sido Muncul collaborates with other businesses from upstream to downstream. The upstream is related to inputs such as raw materials, energy, human resources, and technology. Sido Muncul's herbal raw materials come from one hundred and sixty types of medicinal plants, which are harvested from nature, then research and cultivation are conducted in collaboration with universities, communities, farmers, farmer groups, and farmer cooperatives. Downstream is related to distributors, agents, or marketing and thousands of outlets ranging from specific types of herbal medicine or sales to other products, which aim to strengthen SMEs.

The purpose of this study is to examine the social engagement network in Sido Muncul's CSR, namely, the partnership program with farmers, and how the process of implementing corporate social entrepreneurship in the program is carried out. The contribution of this research is for Sido Muncul to get a detailed picture of the social engagement network and the stages of the implementation of corporate social entrepreneurship to improve its performance, so that the company produces shared value creation for the sustainability of the organization and its fostered partners.

\section{Literature Review}

\subsection{Social Engagement Network}

According to Lorne and Dilling (2012), social entrepreneurship can be successful if it can build relationships between various stakeholders and attract human, social, financial, and intangible resources through partnerships. This partnership can create shared value to achieve strategic goals and objectives, as well as pursue mutually-compatible interests. Partnerships allow companies to acquire resources without paying the full acquisition cost (Lavie, 2012). Organizations form partnerships in organizational networks that act symbiosis through strong or weak ties in certain populations (Granovetter, 2018).

Symbiosis refers to the interdependence between unequal elements and suggests that different network members benefit from each other's presence (Shumate \& O'Connor, 2010). Dana et al. (2008) added that entrepreneurship that has a symbiotic nature can create added value because each of the elements benefits from joint efforts. The symbiotic relationship increases access to information regarding entrepreneurial opportunities, which leads to increased productivity. In symbiotic entrepreneurship, members of small and large networks share power and control to create multi-power networks that increase members' ability to reduce risk and facilitate the achievement of common resources and goals.

\subsection{Corporate Social Entrepreneurship}

CSR and social entrepreneurship produce corporate social entrepreneurship that can address contemporary challenges in an environment that requires sustainable solutions (Agrawal \& Sahasranamam, 2016). Companies can engage with employees to support communities in a sustainable manner, for both profit and non-profit (Jones et al., 2017). In addition, companies need social support and educational support to develop social entrepreneurship in an organization (Akhter et al., 2020).

According to Michelini and Fiorentino (2012), corporate social entrepreneurship enhances the relationship between business, NGOs, and society. The fundamental goal of corporate social entrepreneurship is to refresh and advance the development of CSR by accelerating the transformation of corporate organizations into powerful generators of social improvement (Zaefarian et al., 2015). The corporate social entrepreneurship concept is very valuable in CSR work because it can create business units that use the core 
resources of the company to innovate and create products and services that are socially and financially active (Spitzeck et al., 2013).

Social intrapreneurs are the most centralized and valuable component of the corporate social entrepreneurship model (Agrawal \& Sahasranamam, 2016; Zaefarian et al., 2015). They have access to resources that can help implement their ideas (Grayson et al., 2011), thereby finding practical solutions to sustainability problems (Spitzeck et al., 2013). In some of the most effective corporate social entrepreneurship endeavors worldwide, it is found that social intrapreneurs are at the forefront (Zhang \& Zhang, 2016) as agents of change (Grayson et al., 2011).

\subsection{Corporate Social Entrepreneurship Implementation Process}

Corporate social responsibility can be a way to promote social entrepreneurship (Sanclemente-Téllez, 2017), so that simultaneously companies can contribute to economic, social and environmental goals through strategic investment into their business processes (Carroll \& Shabana, 2010). Through CSR, companies also gain legitimacy and trust from NGOs, communities and government agencies (Agrawal \& Sahasranamam, 2016), as well as produce key concepts, business models, products and services that will open new avenues among various stakeholders (Zhang \& Zhang, 2016).

According to Tasavori et al. (2016), the steps to implement corporate social entrepreneurship to enter the Base of the Pyramid (BOP) market consist of identifying social problems as market opportunities, developing or adapting products and services, developing or adapting marketing processes (for example: promotion, distribution, price). Another case is the implementation of the corporate social entrepreneurship model from India is accompanied by the following steps: commitment of resources, social innovation and creation of new business models, and developing collaborations with NGOs, local entrepreneurs and the government (Agrawal \& Sahasranamam, 2016). The Swedish corporate social entrepreneurship model has implementation steps that includes allocation of resources, partnerships with social sector organizations and/or institutions, and developing and evaluating products and services and marketing processes (Nikolov \& Westergren, 2017).

\section{Research Methods}

This research uses qualitative research methods, with a grounded theory design, which is directed at finding or at least strengthening a theory. The grounded theory approach is an attempt to develop a theory that is hidden behind the data, where the data collected is then analyzed systematically (Martin \& Turner, 1986). This research was conducted in Sido Muncul, namely, in the public relations and CSR section of Sido Muncul, which is located in Semarang Regency, as well as several places where Sido Muncul implements the Partnership Program with Farmers in Indonesia, including in Tawangmangu Village, Karanganyar; Sikunang Village, Wonosobo; Gudang Harjo Village, Parang Gupito; and Gladagsari Village, Boyolali. The Partnership Program with Farmers has been the target of Sido Muncul's CSR for the last six years and is considered quite successful in creating shared value. Triangulation refers to the use of several methods or data sources in qualitative research to develop a comprehensive understanding of phenomena (Carter et al., 2014). Triangulation has also been seen as a qualitative research strategy for testing validity and reliability through convergence of information from multiple sources. This research uses triangulation of data sources and methods by conducting surveys, observations, and interviews with Sido Muncul's Public Relations and CSR Team, as well as the management of farmer groups as Sido Muncul's partners.

\section{Results and Discussion}

\subsection{The Social Engagement Network in Sido Muncul Partnership Program}

Sido Muncul develops corporate social entrepreneurship as an effort to establish community independence and continuity. According to Michelini and Fiorentino (2012), corporate social entrepreneurship enhances the relationship between business, NGOs and society. The fundamental goal of corporate social entrepreneurship is to refresh and advance CSR development by accelerating the transformation of corporate organizations into powerful generators of social improvement (Zaefarian et al., 2015). Corporate social entrepreneurship is divided into two activities, namely, activities that are connected and activities that are not connected. Connected activities are CSR activities directed at the business side, such as planting medicinal plants with assistance activities, such as providing seeds, tools, machines, or training, and Sido Muncul buys the results. Unconnected activities, such as making handicrafts, food \& beverages, and making innovative products through mentoring activities in the form of training, guaranteeing banking credit for SMEs, and managing the marketing mix.

The concept of corporate social entrepreneurship is very valuable in CSR work because it can create business units that use the core resources of the company to innovate and create products and services that are socially and financially active (Spitzeck et al., 2013). Sido Muncul's CSR partnership program with farmers has included elements of social entrepreneurship to sort the appropriate 
commodities in certain locations, thereby improving the community's economy. Partnerships are also influenced by the social, economic and environmental conditions of the community. There are many medicinal plants that are nutritious, which are less known by the wider community, such as stevia, herbal chilies, purwoceng, and cinnamon, which are used as raw materials for herbal medicine. Sido Muncul also facilitates the community to be able to identify various medicinal plants and rare plants that grow in the location, collect information and literature, research aspects of plant cultivation, coordinate with various related parties, map roles, and monitor the implementation of cooperation programs.

Sido Muncul establishes partnerships with farmers, in Karanganyar, Boyolali, Wonosobo, and Parang Gupito, where each has its own specific commodity and social conditions. Commodities that are general in nature or much needed by the public will cause a high level of competition, so that cooperation is more directed towards specific commodities such as herbal chilies in Parang Gupito, purwoceng in Wonosobo, cinnamon in Boyolali, and mint and stevia leaves in Karanganyar. The partnership carried out by Sido Muncul is a mutually beneficial business relationship, which is built involving the roles of the government, NGOs, universities, and the private sector as facilitators and control functions, and this partnership is woven into a cooperation document. This can be seen in Figure 1.

Corporate social entrepreneurship can be successful if it can build relationships between various stakeholders and attract human, social, financial and intangible resources through partnerships. This partnership relationship can create a network of organizations that act symbiosis to achieve strategic goals and objectives, and pursue compatible interests (Granovetter, 2018). Sido Muncul's partnership network with farmer groups has a cooperation system with clear rules and agreement between two parties. The work contract system provides a limit on the activities of farmers to develop their agriculture, such as specifications of goods and prices to be used, quantities to be produced, commitment to efforts to reduce risks, and balance agricultural activities with social benefits. The partnership pattern formed by Sido Muncul has cut the distribution chain, so it is expected to guarantee price and market stability. This can be seen in Figure 2.

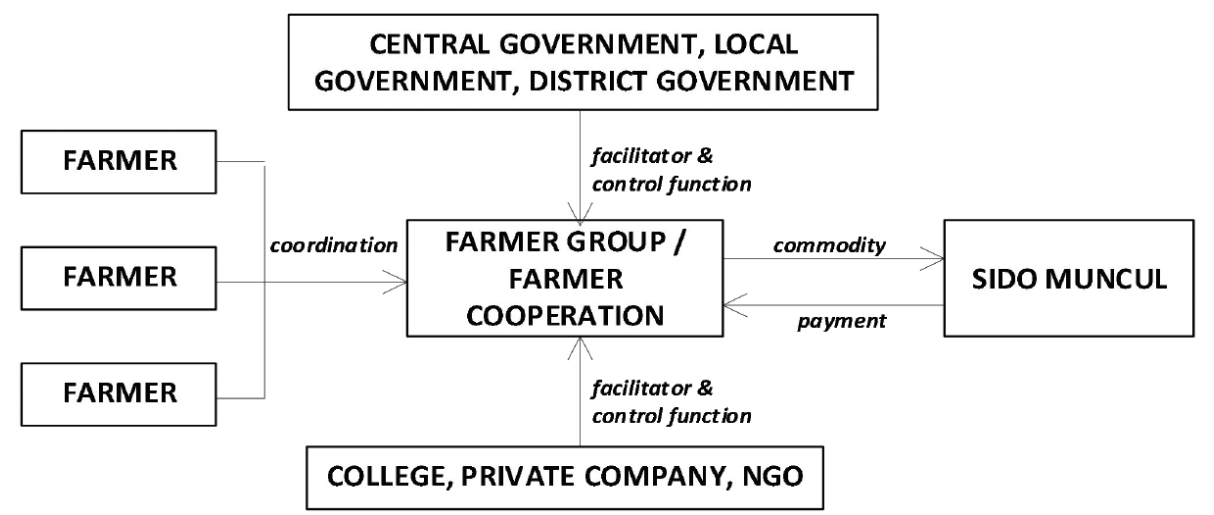

Figure 1: Social Engagement Network for Sido Muncul Partnership Program

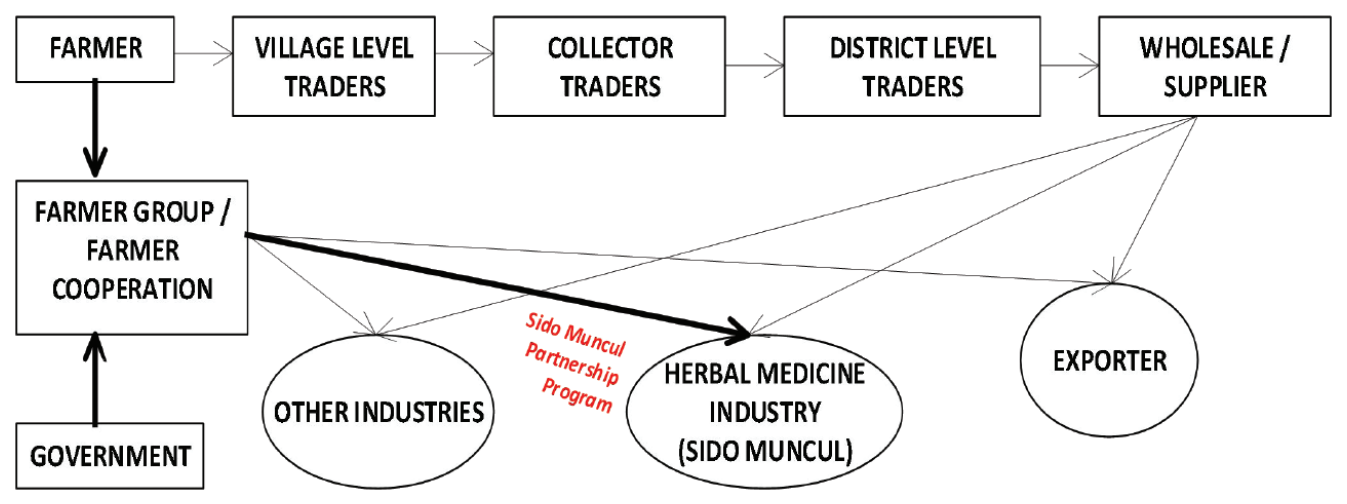

Figure 2: Sido Muncul Partnership Program Distribution Chain 
Sido Muncul's production activities produce 40 tons of dregs of herbal ingredients every day, where some of it is processed into liquid fertilizer which is useful for increasing agricultural production, the rest is processed into biopelets as a renewable energy fuel used for LNG replacement fuel. Biopelet calories reach 5,300 kcal and can be used for drying machines. Biopelets can be sold for only Rp1,100 per kg, because it has low production costs. Sido Muncul can reduce production fuel costs due to the ratio of $1 \mathrm{~kg}$ of gas to $3 \mathrm{~kg}$ of biopelet. Apart from being used alone for heating drying machines, biopelets are also sold to the market to popularize the use of biomass fuel to the public. Sido Muncul also processes ginger dregs into ginger essential oil (zero waste of ginger dregs), utilizes medicinal dregs for boiler fuel to replace fuel oil (BBM) and natural gas $(\mathrm{CNG})$, as well as for fertilizer. Sido Muncul's corporate social entrepreneurship has a symbiotic nature in the social engagement network, where the company and the farmers get added value from the partnership. The symbiotic relationship can increase access to information regarding entrepreneurial opportunities leading to increased productivity.

\subsection{Corporate Social Entrepreneurship Implementation Process}

The first stage of the social enterprise entrepreneurship implementation process is problem identification. Sido Muncul made a social mapping, such as how the typology of the community that is the target of CSR, whether the industrial community or the agricultural community should take CSR policies that benefit both parties. Each Sido Muncul CSR program has a travel map, where this is realized through proposals for CSR activities in the short and long term. Sido Muncul conducts effective and fair integration or interdependence with stakeholders to produce the company's long-term competitive advantage.

The second stage of the social enterprise entrepreneurship implementation process is coordination with related parties. Sido Muncul CSR team coordinates with the target community through pusrembak, social media, such as SMS, WA, or telephone, both with village officials, farmers and farmer groups, as well as with field extension workers to solve problems in the field. Sido Muncul's CSR program is also known by all Sido Muncul employees, both through the website, and Sido Academic who opened a booth with the name Company Credibility to socialize Sido Muncul CSR program, thus giving employees pride, that the company they work for cares about social problems and environment.

The third stage of the process of implementing corporate social entrepreneurship is the allocation and commitment of resources. Sido Muncul allocates resources to meet CSR needs through support from management, in the form of funds, time, Community Development Officer (CDO), even top management. Sido Muncul is committed to empowering target communities, starting from planning, implementation, monitoring and evaluation, by providing agricultural input assistance, machinery and infrastructure procurement, and even assurance of market certainty.

The fourth stage of the corporate social entrepreneurship implementation process is collaboration with NGOs, local entrepreneurs, and the government. Sido Muncul's CSR program adopts knowledge and technology about the effectiveness and impact of the CSR program for the company and target community through collaboration with stakeholders. Sido Muncul does not eliminate local wisdom that has emerged in every region, for example pesticides are replaced by owl cultivation to kill field rats that destroy land and agricultural products; rat assault team, which conducts night patrols to hunt rats traditionally; and a drip irrigation system, which is a bottle filled with water, perforated small size, and hung near the plant for watering so that the plants do not die during the dry season. Sido Muncul develops a wide business network, both from upstream and downstream in collaboration with the community, other companies, research institutes or universities, and the government, in order to increase agricultural productivity and its derivative products, which in turn creates value chains that provide mutual benefits. Sido Muncul CSR program is integrated with the company's business processes, such as a partnership program with farmers, as a company step to ensure the supply of raw materials, in addition to strengthening SMEs or farmer cooperatives in the local area.

The fifth stage of the implementation process of corporate social entrepreneurship is social innovation and the creation of new businesses. Sido Muncul creates social innovations from existing problems in the field such as cultivating herbal chili plants for production raw materials, processing coconut sugar into ant sugar with attractive packaging, processing ginger into ginger candy, ginger simplicia, ginger soap, and so on. Sido Muncul provides assistance with seeds, fertilizers, pesticides, work tools, and machines, as well as providing training and mentoring, both in the process of land preparation, planting, harvesting and post-harvest, so that CSR partners are self-reliant and sustainable. Sido Muncul also looks for a market for products produced by CSR partners, such as making various foods, crafts, and processed products, in several ways, including providing access to consultations, buying agricultural products for factory supplies, and providing distribution channels, namely Sido Tetulung mini market.

The sixth stage of corporate social entrepreneurship implementation process is the documentation of activities. Sido Muncul documents CSR activities through meeting moorings, photos, and reports from CDOs and local heroes in each CSR partner, so that the economic and social impacts of CSR activities can be seen. Sido Muncul reports its 
CSR activities to the PROPER Council of the Ministry of Environment and Forestry, which shows that the company has implemented the indicators contained in the PROPER (Company Performance Rating Program in Environmental Management) for community empowerment. Sido Muncul CSR team monitors and evaluates every CSR activity for the manufacture of scientific journals or books, and improves CSR performance in the future.

The seventh stage of the social enterprise entrepreneurship implementation process is reporting. Sido Muncul CSR activity report is given to the company secretary to be submitted to shareholders, so that it becomes an evaluation material for the investment made in Sido Muncul. Sido Muncul also provides a CSR activity report to the PROPER Council of the Ministry of Environment and Forestry, where the company engages the community in its business processes, resulting in joint value creation. This information and interaction is a social process that can be used as a management tool in avoiding things that are not expected by the company.

The eighth stage of the corporate social entrepreneurship implementation process is monitoring and evaluation. The planning phase of Sido Muncul's CSR program is mapping the problem and determining the CSR program, by doing social mapping, so as to avoid unwanted things in the future, such as commitment and continuity of the CSR program. The implementation stage is carried out in the context of the process of implementing the CSR program in the field by making regular reports on the progress of the CSR program and giving it to Sido Muncul management and the PROPER Council of the Ministry of Environment and Forestry for monitoring and evaluation purposes. The final stage is to measure the success of the CSR program implementation process by conducting an evaluation, in which the evaluation results are reported to the leadership as a form of responsibility and further improvement of the CSR program.
The ninth stage of corporate social entrepreneurship implementation process is publication. Each CSR program is unique, so that the time for publication is also adjusted to the interests of the company and the completeness of the data, it can be at the beginning of the program launch, in the program process, or at the time of the harvest. Apart from using print media, both on a regional, national and international scale, and online media such as Indosiar, Metro $\mathrm{TV}$, and others, publications are also carried out face-toface, that is, when guests visit Sido Muncul. The company also invites stakeholders at the launch and celebration of the success of its CSR programs, so as to create a harmonious relationship between shareholders and stakeholders.

Based on the explanation above, it can be concluded that the implementation process of corporate social entrepreneurship has nine stages illustrated in Figure 3.

Figure 3 explains that the collaboration stage with NGOs, local entrepreneurs, and the government has four empirical indicators. Furthermore, the social innovation stage and the creation of new businesses, the activity documentation stage, the monitoring and evaluation stage, and the publication stage each have three empirical indicators. The problem identification stage, the coordination with related parties, the allocation and commitment stage of resources, and the reporting stage each have two empirical indicators.

\section{Conclusions}

Sido Muncul CSR program social engagement network is related to the roles of the government, NGOs, universities, and the private sector as facilitators and control functions, and is woven into a cooperation document, so as to create mutually beneficial business relationships. Sido Muncul, with a farmer group running a partnership with clear rules and agreement between the two parties, including specifications of goods and prices to be used, the amount to be produced, commitment to efforts to reduce risks, and balance

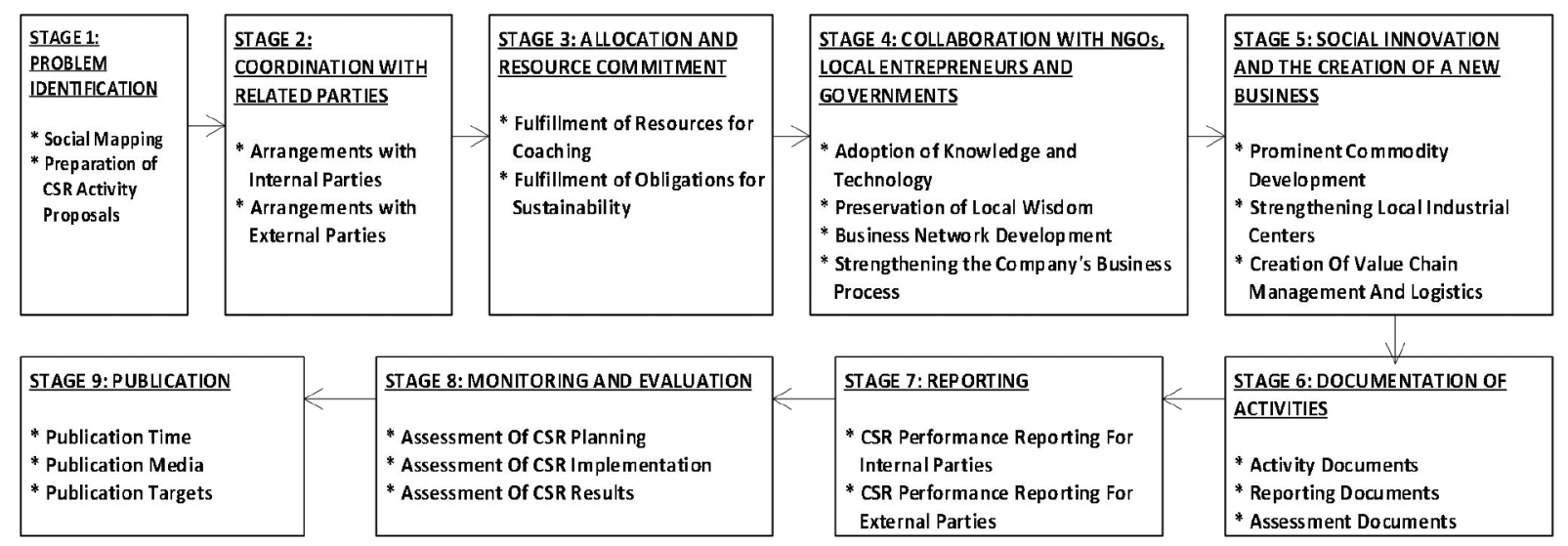

Figure 3: Corporate Social Entrepreneurship Implementation Process 
agricultural activities with social benefits obtained. The process of implementing corporate social entrepreneurship in Sido Muncul's CSR for a partnership program with farmers consists of nine stages, including problem identification; coordination with related parties; resource allocation and commitment; collaboration with NGOs, local entrepreneurs and government; social innovation and the creation of new businesses; documentation of activities; reporting; monitoring and evaluation; and publications.

The recommendation regarding social engagement networks is that Sido Muncul can evaluate the work contract system with farmers based on the shared value generated. For this reason, companies can create evaluation instruments containing cost and benefit analysis, which can be used to make decisions, whether the partnership program will continue, be modified with new variables, or terminated. In addition, Sido Muncul can also increase cooperation with the government and industry in dealing with scarcity of raw materials, waste, technological innovation, or the creation of new businesses that contribute to 3P (planet, profit, and people). Recommendations regarding the implementation process of corporate social entrepreneurship are given for the collaboration stage with NGOs, local entrepreneurs and the government (fourth stage); social innovation and the creation of new businesses (fifth stage); as well as documentation of activities (sixth stage). For the collaboration stage with NGOs, local entrepreneurs, and the government, Sido Muncul can continuously build trust, respect each other, organize strategies, facilitate communication, review performance, and provide feedback to parties involved in implementing CSR programs, so that the objectives together can be fulfilled. For the social innovation stage and the creation of new businesses, Sido Muncul can do brainstorming to get new ideas in carrying out innovative and participatory CSR programs. Therefore, Sido Muncul can partner with research institutions, consultants, or learning societies, so as to produce inspiring and creative CSR products, which are beneficial for the lives of many people. For the documentation phase of activities, Sido Muncul can prepare CSR activity instruments, such as procedures, work instructions, and records in order to obtain structured and systematic data for the purposes of planning, implementing, and evaluating CSR programs.

\section{References}

Agrawal, A., \& Sahasranamam, S. (2016). Corporate social entrepreneurship in India. South Asian Journal of Global Business Research, 5(2), 214-233. https://doi.org/10.1108/ SAJGBR-12-2014-0098

Akhter, A., Hossain, M. U., \& Al Asheq, A. (2020). Influential factors of social entrepreneurial intention in Bangladesh. Journal of Asian Finance, Economics and Business, 7(8), 645651. https://doi.org/10.13106/jafeb.2020.vol7.no8.645
Carroll, A. B., \& Shabana, K. M. (2010). The Business Case for Corporate Social Responsibility: A Review of Concepts, Research and Practice. International Journal of Management Reviews, 12(1), 85-105. https://doi.org/10.1111/j.14682370.2009.00275.x

Carter, N., Bryant-Lukosius, D., DiCenso, A., Blythe, J., \& Neville, A. J. (2014). The Use of Triangulation in Qualitative Research. Oncology Nursing Forum, 41(5), 545-547. https:// doi.org/10.1188/14.ONF.545-547

Crisan, C., \& Borza, A. (2012). Social Entrepreneurship and Corporate Social Responsibilities. International Business Research. https://doi.org/10.5539/ibr.v5n2p106

Dana, L. P., Etemad, H., \& Wright, R. W. (2008). Toward a paradigm of symbiotic entrepreneurship. International Journal of Entrepreneurship and Small Business, 5(2), 109-126. https:// doi.org/10.1504/IJESB.2008.016587

Granovetter, M. (2018). Economic action and social structure: The problem of embeddedness. The Sociology of Economic Life, 91(3), 22-45. https://doi.org/10.4324/9780429494338

Grayson, D., Mclaren, M., \& Spitzeck, H. (2011). Social Intrapreneurs-An Extra Force for Sustainability A Doughty Centre for Corporate Responsibility Occasional Paper, (February). Retrieved from www.volans.com

Jones, D. A., Willness, C. R., \& Glavas, A. (2017). When corporate social responsibility (CSR) meets organizational psychology: New frontiers in micro-CSR research, and fulfilling a quid pro quo through multilevel insights. Frontiers in Psychology, 8(March), 1-14. https://doi.org/10.3389/fpsyg.2017.00520

Lavie, D. (2012). The Competitive Advantage of Interconnected Firms. 21st Century Management: A Reference Handbook, I-324-I-334. https://doi.org/10.4135/9781412954006.n32

Lorne, F. T., \& Dilling, P. (2012). Creating Values for Sustainability: Stakeholders Engagement, Incentive Alignment, and Value Currency. Economics Research International. https://doi. org/10.1155/2012/142910

Machmuddah, Z., Sari, D. W., \& Utomo, D. (2020). Corporate social responsibility, innovation and firm value: Evidence from Indonesia. Journal of Asian Finance, Economics and Business, 7(9), 631-638. https://doi.org/10.13106/jafeb.2020. vol7.no9.631

Martin, P. Y., \& Turner, B. A. (1986). Grounded Theory and Organizational Research. The Journal of Applied Behavioral Science, 22(2), 141-157. https://doi. org/10.1177/002188638602200207

Michelini, L. (2012). Corporate Social Entrepreneurship and New Business Models. In Social Innovation and New Business Models (pp. 19-35). Berlin, Heidelberg: Springer Berlin Heidelberg. Retrieved from http://link.springer.com/10.1007/978-3-64232150-4_2

Michelini, L., \& Fiorentino, D. (2012). New business models for creating shared value. Social Responsibility Journal, 8(4), 561-577. https://doi.org/10.1108/17471111211272129

Mushka, D. (2015). Creating Value for Corporate Sustainability: Stakeholder Engagement. Master's Thesis University. Strategy, 
Innovation, and Sustainability, School of Business and Management, Lappeenranta University of Tehcnology.

Nguyen, T. H., \& Tu, V. B. (2020). Social responsibility, organizational commitment, and organizational performance: Food processing enterprises in the mekong river delta. Journal of Asian Finance, Economics and Business, 7(2), 309-316. https://doi.org/10.13106/jafeb.2020.vol7.no2.309

Nikolov, A., \& Westergren, L. (2017). Corporate Social Entrepreneurship as a new approach to CSR-A Swedish Outlook, Departement of Business Administration, Lund University, http://lup.lub.lu.se/student-papers/record/8915321

Raimi, L., Akhuemonkhan, I., \& Ogunjirin, O. D. (2015). Corporate Social Responsibility and Entrepreneurship (CSRE): Antidotes to poverty, insecurity and underdevelopment in Nigeria. Social Responsibility Journal. https://doi.org/10.1108/SRJ-11-20120138

Sanclemente-Téllez, J. C. (2017). Marketing and Corporate Social Responsibility (CSR). Moving between broadening the concept of marketing and social factors as a marketing strategy. Spanish Journal of Marketing - ESIC, 21, 4-25. https://doi. org/10.1016/j.sjme.2017.05.001

Shumate, M., \& O'Connor, A. (2010). The symbiotic sustainability model: Conceptualizing NGO-corporate alliance communication. Journal of Communication, 60(3), 577-609. https://doi.org/10.1111/j.1460-2466.2010.01498.x

Spitzeck, H., Boechat, C., \& França Leão, S. (2013). Sustainability as a driver for innovation - towards a model of corporate social entrepreneurship at Odebrecht in Brazil. Corporate Governance: The International Journal of Business in Society, 13(5), 613-625. https://doi.org/10.1108/CG-06-2013-0080

Tasavori, M., Ghauri, P. N., \& Zaefarian, R. (2016). Entering the base of the pyramid market in India: A corporate social entrepreneurship perspective. International Marketing Review, 33(4), 555-579. https://doi.org/10.1108/IMR-03-2014-0085

Zaefarian, R., Tasavori, M., \& Ghauri, P. N. (2015). A Corporate Social Entrepreneurship Approach to Market-Based Poverty Reduction. Emerging Markets Finance and Trade, 51(2), 320334. https://doi.org/10.1080/1540496X.2015.1021606

Zahari, A. R., Esa, E., Rajadurai, J., Azizan, N. A., \& Tamyez, P. F. M. (2020). The effect of corporate social responsibility practices on brand equity: An examination of malaysia's top 100 brands. Journal of Asian Finance, Economics and Business, 7(2), 271280. https://doi.org/10.13106/jafeb.2020.vol7.no2.271

Zhang, H., \& Zhang, M. (2016). The Corporate Social Entrepreneur: From Concept to Practice. Global Business and Organizational Excellence, 35(2), 50-59. https://doi.org/10.1002/joe.21655 